\title{
RANCANG BANGUN SISTEM PENGENALAN WAJAH DENGAN METODE PRINCIPAL COMPONENT ANALYSIS
}

\author{
${ }^{1)}$ Salamun, ${ }^{2)}$ Firman Wazir \\ ${ }^{1,2)}$ Program Studi Teknik Informatika, Fakultas Teknik, Univbersitas Abdurrab Pekanbaru \\ ${ }^{1,2)}$ Jl. Riau Ujung No. 73 Pekanbaru \\ E-Mail : salamun@univrab.ac.id,Firmanwazir@gmail.com
}

\begin{abstract}
ABSTRAK
Wajah merupakan salah satu ukuran fisiologis yang paling mudah dan sering digunakan untuk membedakan identitas individu yang satu dengan yang lainnya. Proses pengenalan wajah ini menggunakan informasi mentah dari pixel citra yang dihasilkan melalui camera yang kemudian direpresentasikan dalam metode Principal Components Analysis. Adapun cara kerja metode Principal Components Analysis adalah dengan menghitung dari rata-rata flatvector pixel dari gambar-gambar yang sudah disimpan dalam suatu database, dari rata-rata flatvector tersebut akan didapatkan nila eigenface masing-masing gambar dan kemudian akan dicari nilai eigenface terdekat dari gambar citra wajah yang ingin dikenali. Hasil pengujian menunjukkan tingkat keberhasilan pengenalan wajah secara keseluruhan sebesar 82,27\% dengan data wajah sebanyak 130 gambar.
\end{abstract}

Kata Kunci : PCA, Eigenface, Flatvector, Pengenalan Wajah.

\section{ABSTRACT}

The face was one of the easiest physiological measure and often used to distinguish the identity of one individual to another. The face recognition process using the raw information from the pixel image produced by the camera was then represented in the Principal Components Analysis method. As for how the Principal Components Analysis method was to calculate the average flatvector pixel of the images that have been stored in a database, from an average of flatvector will be obtained tilapia Eigenface each image and then look for the value Eigenface closest pictures face image that you want to identify. The test results show a success rate of face recognition as a whole by $82,27 \%$ with the data face as many as 130 images.

Keywords : PCA, Eigenface, Flatvector, Face Recognition.

\section{PENDAHULUAN}

Teknologi di bidang informasi khususnya dengan menggunakan komputer yang telah tumbuh semakin pesat, berbagai macam aplikasi telah dirancang untuk mencari informasi tentang data diri seseorang. Salah satu aplikasi yang cukup dikenal dalam hal ini adalah aplikasi pengenalan wajah (face recognition). Aplikasi face recognition pada saat ini banyak dikembangkan karena dapat diaplikasikan di berbagai bidang permasalahan, salah satu contohnya adalah pengenalan kriminal, system security. Sistem identifikasi seseorang berbasiskan wajah atau biasa disebut sistem pengenalan wajah, memang baru-baru ini mulai digunakan pada bidang biometrika, apakah sistem ini bisa menjadi solusi alternatip untuk di terapkan pada sistem keamanan.

Sama hal nya dengan sidik jari dan retina mata manusia, wajah bersifat nonidentik karena setiap orang memiliki bentuk dan kontur wajah yang berbeda-beda, sehingga wajah bisa dijadikan alat atau model untuk dipakai dalam mengidentifikasi seseorang. Sistem pengenalan wajah adalah suatu sistem yang membuat sebuah mesin dapat mengenali wajah seseorang sesuai dengan gambar wajah yang telah dilatih dan disimpan di dalam mesin tersebut.

Untuk membangun sistem pengenalan wajah yang baik agar dapat diterapkan pada sistem identifikasi seseorang, sistem tersebut harus memenuhi beberapa kriteria diantaranya keakuratan pengenalan dan kecepatan 
pengenalan. Dengan adanya masalah tersebut maka diperlukan suatu analisis terhadap system pengenalan wajah, oleh karena itu dilakukan penelitian tentang analisis sistem pengenalan wajah dengan metode principal component Analysis. Metode Principal Component Analysis (PCA) merupakan salah satu metode implementasi yang banyak digunakan untuk pengenalan pola dan image coding.

\section{Rumusan Masalah}

Berdasarkan uraian latar belakang diatas, maka penulis dapat merumuskan permasalahan yang diteliti, yaitu :

1. Bagaimana dapat mengenali suatu pola, khususnya pola wajah?

2. Bagaimana membangun aplikasi pengenalan wajah menggunakan metode Principal Component Analysis ?

3. Apakah pengenalan wajah dengan menggunakan metode Principal Component Analysis dapat mencapai presentase keberhasilan diatas $50 \%$ ?

4. Bagaimana melakukan proses pengenalan citra wajah menggunakan metode Principal Component Analysis?

\section{Batasan Masalah}

Untuk menjaga fokus dari penelitian ini, maka beberapa batasan yang diberikan adalah sebagai berikut :

1. Wajah yang akan dideteksi adalah wajah yang menghadap ke depan (frontal), dalam posisi tegak, dan tidak terhalangi sebagian oleh objek lain.

2. Jarak antara wajah dengan kamera kurang lebih $30 \mathrm{~cm}$ sampai $50 \mathrm{~cm}$.

3. Pencahayaan di lingkungan sekitar wajah harus terang (minimal ada sumber cahaya yang menghadap ke wajah yang akan ditangkap oleh kamera).

4. Gambar di ambil secara realtime

5. Bahasa yang akan digunakan adalah bahasa C\# dan Library EmguCV
6. Capture device yang digunakan adalah Android-camera.

\section{Tujuan}

Penelitian yang dilakukan memiliki tujuan sebagai berikut :

1. Mengukur tingkat keberhasilan pengenalan wajah dengan menggunakan algoritma Principal Component Analysis (PCA) sesuai dengan batasan yang telah ditentukan.

1. Menghasilkan aplikasi pengenalan wajah menggunakan metode Principal Component Analysis.

\section{Manfaat}

Beberapa manfaat yang diperoleh dari penelitian yang dilakukan :

1. Dapat mencari informasi orang yang melakukan kejahatan atau pelanggaran melalui foto yang telah di scan.

2. Dapat mengukur kecepatan dalam pengenalan wajah menggunakan metode principal componen tAnalysis.

3. Diharapkan hasil penelitian ini dapat membantu pengembangan aplikasiaplikasi yang lebih kompleks seperti sistem keamanaan menggunakan wajah.

\section{Pengenalan Wajah}

Pengenalan wajah adalah suatu metoda pengenalan yang berorientasi pada wajah. Pengenalan ini dapat dibagi menjadi dua bagian yaitu : Dikenali atau tidak dikenali, setelah dilakukan perbandingan dengan pola yang sebelumnya disimpan di dalam database (Marti, 2010). Secara umum, sistem pengenalan citra wajah dibagi menjadi 2 jenis, yaitu sistem feature based dan imagebased. Pada sistem pertama digunakan fitur yang diekstraksi dari komponen citra wajah (mata, hidung, mulut, dll) yang kemudian hubungan antara fitur-fitur tersebut dimodelkan secara geometris. Sedangkan sistem kedua menggunakan informasi mentah 
dari piksel citra yang kemudian direpresentasikan dalam metode tertentu, yang kemudian digunakan untuk klasifikasi identitas citra (Fatta, 2009).

\section{Pendeteksi Wajah}

Proses pendeteksi wajah ini bekerja dengan cara memeriksa citra yang dimasukan, apakah memiliki citra wajah atau tidak, jika memiliki, maka akan dilakukan pemisahan dengan cara memotong citra wajah dari latar belakang citra yang dimasukan. Jika masukan berbentuk video, proses yang dilakukan adalah proses face tracking. Secara umum, proses face tracking dan proses pendeteksian wajah mempunyai fungsi yang sama. Perbedaannya terletak pada proses pendeteksiannya saja, jika pada masukan berbentuk citra, sistem berjalan offline sehingga dapat menggunakan proses pendeteksian wajah, sedangkan pada masukan video, sistem berjalan secara online atau realtime yang membutuhkan pendeteksian secara langsung maka proses yang digunakan adalah proses face tracking.

\section{Penyelarasan Wajah}

Pada proses pendeteksian wajah, citra wajah yang didapatkan masih berupa perkiraan kasar atau masih memiliki kualitas yang cukup buruk seperti ukuran yang berbeda dengan ukuran normal, faktor pencahayaan yang kurang atau lebih, kejelasan citra yang buruk dan sebagainya. Maka perlu diadakannya proses penyelarasan. Proses penyelarasan wajah merupakan proses yang bertujuan untuk menormalisasi wajah dari citra wajah yang didapatkan dari proses pendeteksian wajah. Proses ini terdiri dari tahapan-tahapan sebagai berikut:

\section{Grayscaling}

Grayscaling citra merupakan tahapan pertama dari proses penyelarasan, pada tahap ini terjadi pengkonversian citra warna RGB menjadi citra berwarna abu.
Citra warna RGB terdiri dari 3 parameter warna yaitu merah (red), hijau (green) dan biru (blue), jika citra warna RGB ini dimasukan ke dalam proses ekstraksi, maka proses tersebut akan sulit untuk dilakukan karena citra RGB terdiri dari 3 parameter, oleh karena itu diperlukan penyamaan parameter yaitu dengan melakukan tahap grayscaling ini.

2. Pemotongan

Pada tahapan ini terjadi pemotongan citra yang memisahkan citra wajah dengan citra masukannya, tujuannya untuk mengambil citra yang hanya diperlukan untuk proses ekstraksi, dalam hal ini adalah citra wajah dan membuang citra lain yang tidak diperlukan. Dimensi citra yang dipotong disesuaikan dengan dimensi dari proses segmentasi atau pengkotakan objek wajah yang dilakukan pada proses pendeteksian wajah.

3. Resizing (tahap normalisasi dimensi citra)

Pada tahap resizing citra, terjadi proses normalisasi dimensi citra wajah, yaitu proses pembesaran atau pengecilan dimensi citra wajah menjadi dimensi yang telah ditentukan. Tujuannya, untuk menyamakan dimensi wajah dari tiap citra yang dimasukan, sehingga pada proses ekstraksi citra nanti tidak ada perbedaaan dimensi dari matriks data citra wajah.

4. Equalizing (tahap koreksi tingkat kecerahan citra)

Tahap ini adalah tahapan terakhir dari proses penyelarasan, yang tujuannya untuk memperjelas nilai histogram dari citra wajah hasil tahapan-tahapan sebelumnya.

\section{Ekstrasi Wajah}

Ekstraksi fitur adalah proses untuk mendapatkan ciri-ciri pembeda yang membedakan suatu sampel wajah dari sampel 
wajah yang lain (Damayanti et al, 2010). Ekstraksi fitur merupakan proses yang berfungsi untuk mendapatkan informasi yang efektif dan berguna untuk membedakan wajah-wajah orang yang berbeda dari citra wajah yang telah diselaraskan. Proses ini dilakukan menggunakan algoritma-algoritma ekstraksi seperti principal component analysis (PCA), linear discriminant analysis (LDA), independent component analysis (ICA) dan sebagainya. Informasi yang didapatkan dari ekstraksi fitur disebut vektor fitur, yaitu bentuk dasar pencarian citra berbasis konten, yang menangkap properti citra seperti warna dan tekstur.

\section{Penyimpanan Fitur Wajah}

Proses penyimpanan fitur merupakan tahapan terakhir dari proses pelatihan citra wajah. Proses ini berfungsi untuk menyimpan fitur hasil ekstraksi citra wajah yang ada di dalam database ke dalam sebuah file berekstensi $*$.xml. File inilah yang nantinya akan digunakan untuk proses pencocokan antara citra wajah yang diuji dengan hasil ekstraksi fitur yang terdapat pada file ini.

\section{Pencocokan Fitur Wajah}

Pencocokan fitur merupakan proses perbandingan fitur yang telah diekstrak dari citra uji dengan fitur citra wajah dari database, yang sebelumnya telah melalui proses pelatihan citra.

Dari proses perbandingan fitur tersebut akan menghasilkan nilai jarak terdekat yang menandakan nilai fitur citra uji hampir menyamai dengan fitur citra latih. Nilai jarak ini akan menjadi nilai masukan untuk nilai kemiripan citra.

Nilai kemiripan citra merupakan nilai tingkat kemiripan citra uji dengan citra latih, semakin besar nilainya menandakan bahwa orang yang sedang diamati adalah orang yang sama dengan orang yang citra wajahnya telah disimpan dalam database. Nilai kemiripan ini sebelum mengeluarkan output hasil pengenalan wajah akan melalui proses threshold terlebih dahulu.

Proses threshold pengenalan wajah adalah proses penyaringan nilai kemiripan citra, dimana jika nilai kemiripan berada dibawah threshold yang telah ditentukan maka output hasil pengenalan tidak akan ditampilkan. Jika, berada diatas output hasil pengenalan akan ditampilkan. Tujuannya agar output hasil pengenalan yang ditampilkan bernilai benar, karena memiliki nilai kemiripan yang tinggi. Setelah, proses-proses tersebut dilakukan proses terakhir adalah proses pencarian tingkat keakuratan. Keakuratan adalah kondisi yang menunjukan kebenaran atau ketepatan suatu objek yang diamati, dalam sistem pengenalan ini adalah kebenaran bahwa citra wajah yang diujikan benar-benar citra wajah orang yang dimaksud.

\section{Metode Principal Component Analysis (PCA)}

Principal Componen Analysis (PCA) adalah sebuah cara untuk mengidentifikasi pola pada data dan kemudian mengekspresikan data tersebut ke bentuk yang lain untuk menunjukkan perbedaan dan persamaan antar pola. Tujuan dari PCA adalah untuk mereduksi dimensi yang besar dari ruang data (observed variables) menjadi dimensi yang lebih kecil dari ruang fitur (independent variables), yang dibutuhkan untuk mendeskripsikan data lebih sederhana. Ruang fitur adalah ciri yang digunakan sebagai kriteria dalam pengklasifikasian (Pertiwi \& Harjoko, 2013). Principal Component Analysis menggunakan vektorvektor yang disebut dengan eigenvector dan nilai-nilai yang disebut dengan eigenvalue untuk mendapatkan fitur yang paling signifikan pada dataset. Prinsip dasar dari algoritma Principal Component Analysis adalah mengurangi satu set data namun tetap mempertahankan sebanyak mungkin 
variasi dalam set data tersebut. Secara matematis Principal Component Analysis mentransformasikan sebuah variabel yang berkolerasi ke dalam bentuk yang bebas tidak berkolerasi.

Algoritma Principal Component Analysis (PCA) merupakan salah satu metode yang dapat digunakan untuk mengolah citra wajah seseorang sehingga secara otomatis sistem akan mengenali wajah seseorang melalui ciri-ciri utamanya seperti mata, hidung, bibir, alis sebagai identitas. Identitas dari citra wajah seseorang tersebut oleh sistem akan dikenali melalui berbagai pelatihan (training) yang disimpan di database. Fase pelatihan (training) merupakan hasil ekstraksi dari kumpulan berbagai wajah yang berbeda kemudian dikumpulkan dan disimpan disebuah database. Hasil citra wajah yang telah diekstraksi menggunakan algoritma PCA tersebut nantinya akan dibandingkan dengan citra wajah baru sebagai citra wajah yang akan dites apakah mempunyai kemiripan atau hampir mirip untuk dikenali oleh sistem.

Dalam pattern recognition, fitur-fitur suatu citra menggunakan PCA direpresentasikan sebagai eigenvectors. Eigenvectors didefinisikan sebagai kumpulan hubungan karakteristik-karakteristik dari suatu citra untuk mengenali citra tersebut secara spesifik.

\section{Algoritma Principal Component Analysis (PCA)}

Algoritma pengenalan wajah menggunakan Principal Component Analysis dimulai dengan membuat matriks kolom dari wajah yang di-input ke dalam database. Matriks kolom tersebut akan diubah menjadi bentuk flatvector untuk dicari Rata-rata vector citra dari gambar wajah atau disebut dengan Rataan FlatVector. Rataan FlatVector dihitung dengan cara membagi penjumlahan dari seluruh flatvector citra dengan jumlah banyaknya citra yang disimpan di dalam database.

\section{Penyusunan Flatvector Matriks Citra}

Langkah pertama adalah menyusun seluruh training image menjadi 1 matriks tunggal. Misalnya image yang kita simpan berukuran $\mathrm{H} \times \mathrm{W}$ pixel dan jumlahnya $\mathrm{N}$ buah, maka memiliki flatvector dengan dimensi N x (H x W). Representasikan semua matriks training menjadi matriks dengan bentuk $\mathrm{N}$ x 1 atau matriks linier seperti yang ditunjukkan pada gambar 2.1.

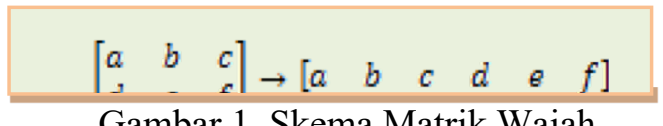

Gambar 1. Skema Matrik Wajah

Contoh dibawah ini mengunakan empat wajah citra yang telah diubah menjadi matriks, lalu matriks tersebut diubah kedalam bentuk rataan FlatVector.

$$
\begin{aligned}
& C_{1} \rightarrow\left[\begin{array}{lll}
11 & 11 & 11 \\
11 & 11 & 11 \\
11 & 11 & 11
\end{array}\right] \rightarrow\left[\begin{array}{llllll}
11 & 11 & 11 & 11 & 11 & 11
\end{array}\right. \\
& C_{2} \rightarrow\left[\begin{array}{lll}
2 & 2 & 2 \\
2 & 2 & 2 \\
2 & 2 & 2
\end{array}\right] \rightarrow\left[\begin{array}{lllllllll}
2 & 2 & 2 & 2 & 2 & 2 & 2 & 2 & 2
\end{array}\right] \\
& C_{\mathrm{a}} \rightarrow\left[\begin{array}{lll}
9 & 9 & 9 \\
9 & 9 & 9 \\
9 & 9 & 9
\end{array}\right] \rightarrow\left[\begin{array}{lllllllll}
9 & 9 & 9 & 9 & 9 & 9 & 9 & 9 & 9
\end{array}\right] \\
& C_{4} \rightarrow\left[\begin{array}{lll}
8 & 8 & 8 \\
8 & 8 & 8 \\
8 & 8 & 8
\end{array}\right] \rightarrow\left[\begin{array}{lllllllll}
8 & 8 & 8 & 8 & 8 & 8 & 8 & 8 & 8
\end{array}\right]
\end{aligned}
$$

\section{Hitung Rata-rata Flatvector}

Dari FlatVector yang diperoleh, jumlahkan seluruh barisnya dan bagi dengan jumlah image training untuk mendapatkan Rata-rata (mean) FlatVector.

$$
\begin{gathered}
\text { Rata-rata flatvector }=\frac{\mathrm{Cl}_{1}+\mathrm{C2}+\cdots+C \mathrm{Cn}}{n} \\
=\left[\begin{array}{ccccccccc}
9 & 9 & 9 & 9 & 9 & 9 & 9 & 9 & 9 \\
2 & 2 & 2 & 2 & 2 & 2 & 2 & 2 & 2 \\
11 & 11 & 11 & 11 & 11 & 11 & 11 & 11 & 11 \\
8 & 8 & 8 & 8 & 8 & 8 & 8 & 8 & 8
\end{array}\right]
\end{gathered}
$$


$=\frac{30+30+30+30+30+30+30+30+30}{4}$

$=[7.57 .57 .57 .57 .57 .57 .57 .57 .5]$

\section{Tentukan Nilai Eigenface}

Dengan menghitung rataan flatvector citra, maka nilai eigenface untuk matriks flatvector yang sudah disusun tersebut dapat dihitung nilai eigenface-nya. Caranya dengan mengurangi baris- baris pada matriks flatvector dengan rata-rata flatvector. Jika didapatkan nilai di bawah nol (nilai minus), maka nilainya diganti dengan nol.

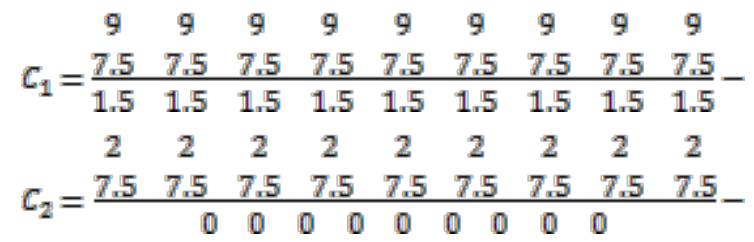

$\begin{array}{lllllllll}11 & 11 & 11 & 11 & 11 & 11 & 11 & 11 & 11\end{array}$

$C_{\mathrm{a}}=\begin{array}{lllllllll}7.5 & 7.5 & 7.5 & 7.5 & 7.5 & 7.5 & 7.5 & 7.5 & 7.5 \\ 3.5 & 3.5 & 3.5 & 3.5 & 3.5 & 3.5 & 3.5 & 3.5 & 3.5\end{array}$

$C_{4}=$\begin{tabular}{ccccccccc}
8 & 8 & 8 & 8 & 8 & 8 & 8 & 8 & 8 \\
\hline 0.5 & 7.5 & 7.5 & 7.5 & 7.5 & 7.5 & 7.5 & 7.5 & 7.5 \\
0.5 & 0.5 & 0.5 & 0.5 & 0.5 & 0.5 & 0.5 & 0.5
\end{tabular}

\subsubsection{Proses Identifikasi}

Untuk mengenali citra tes (testface)

pada saat uji, langkah identifikasinya adalah hitung nilai eigenface untuk matriks testface dengan cara yang sama seperti sebelumnya yaitu dimulai dari awal penentuan nilai flatvector, dikurangi dengan rata- rata FlatVector (didapat dari citra training), dan mendapatkan eigenface untuk testface

$$
C t=\left[\begin{array}{lll}
8 & 9 & 9 \\
9 & 6 & 9 \\
9 & 9 & 7
\end{array}\right] \rightarrow\left[\begin{array}{lllllllll}
8 & 9 & 9 & 9 & 6 & 9 & 9 & 9 & 7
\end{array}\right]
$$$$
=\left[\begin{array}{ccccccccc}
8 & 9 & 9 & 9 & 6 & 9 & 9 & 9 & 7 \\
7.5 & 7.5 & 7.5 & 7.5 & 7.5 & 7.5 & 7.5 & 7.5 & 7.5 \\
\hline 0.5 & 1.5 & 1.5 & 1.5 & 0 & 1.5 & 1.5 & 1.5 & 0
\end{array}\right]
$$

DOI : https://doi.org/10.36341/rabit.v1i2.25 metode $\begin{array}{crr}\text { Identifikasi } & \text { dilakukan } & \text { dengan } \\ \text { Euclidean } & \text { Distance } & \text { yaitu }\end{array}$ menentukan jarak (distance) terpendek antara nilai eigenface dari training image di database dengan eigenface dari testface. Proses dimulai dengan menentukan nilai absolut dari pengurangan matriks eigenface training image dengan eigenface dari testface dan jumlahkan seluruh elemen penyusun vector yang dihasilkan. Kemudian cari nilai paling kecil dari hasil penjumlahan tersebut.

$$
\text { |identify } C n \mid=\frac{\begin{array}{c}
\text { Eigenface Training } \\
\text { Eigenface Testface }
\end{array}}{a b c d f g h i j \ldots .}
$$

1.51 .51 .51 .51 .51 .51 .51 .5

$|C 1|=\frac{0.51 .51 .51 .501 .51 .51 .50}{10001.50001 .5}$

$=1+0+0+0+1.5+0+0+0+1.5$

$=4$

$$
\begin{aligned}
& \begin{array}{llllllll}
0 & 0 & 0 & 0 & 0 & 0 & 0 & 0
\end{array} \\
& |C 2|=\frac{0.51 .51 .51 .501 .51 .51 .50}{0.51 .51 .51 .501 .51 .51 .50}- \\
& =0.5+1.5+1.5+1.5+0+1.5+1.5+1.5+0 \\
& =9.5
\end{aligned}
$$$$
3.53 .53 .53 .53 .53 .53 .53 .53 .5
$$$$
|C 3|=\frac{0.51 .51 .51 .501 .51 .51 .50}{32223.52223 .5}-
$$$$
=3+2+2+2+3.5+2+2+2+3.5
$$$$
=22
$$$$
\begin{aligned}
& |C 4|=\frac{0.50 .50 .50 .50 .50 .50 .50 .50 .5}{0.51 .51 .51 .501 .51 .51 .50} \\
& =01110.51110 .5
\end{aligned}
$$

Dari hasil perhitungan diperoleh jarak citra wajah satu memiliki nilai yang terkecil yaitu 4. Karena jarak eigenface face satu dengan eigenface testface paling kecil, maka hasil identifikasi menyimpulkan bahwa testface lebih mirip dengan face satu dari pada face dua, face tiga, dan face empat. 


\section{METODE}

\section{Kerangka Penelitian}

Kerangka penelitian menjelaskan tentang langkah dan tahapan-tahapan yang dilakukan selama penelitian untuk memudahkan penulis dalam mengerjakan tugas akhir ini.

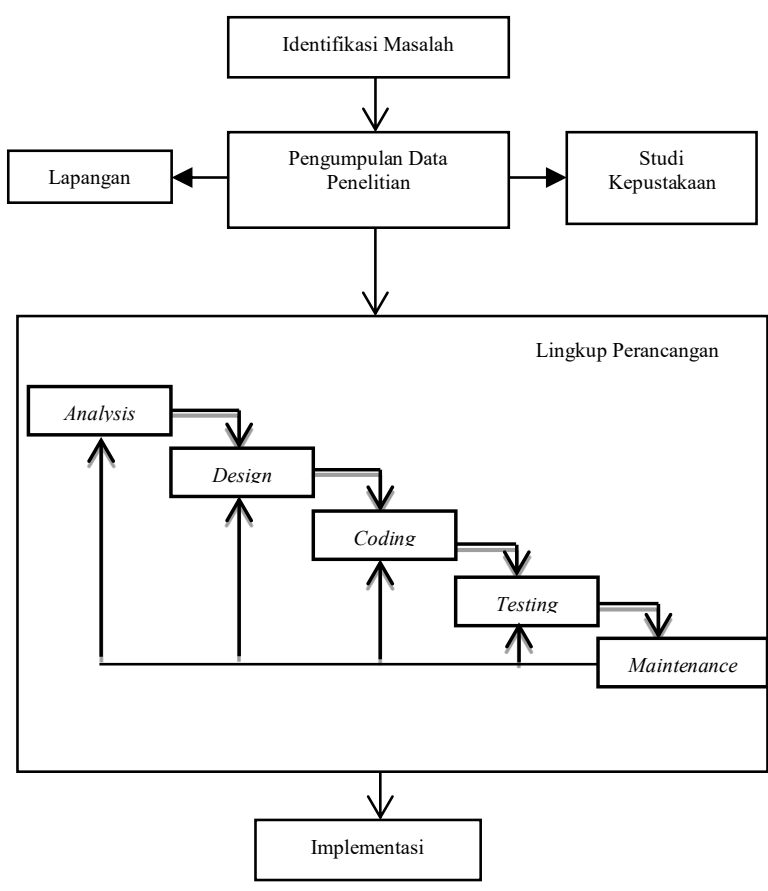

Gambar 2. Kerangka Penelitian

\section{Identifikasi Masalah}

Identifikasi masalah adalah salah satu proses penelitian yang boleh dikatakan penting diantara proses lain. Dalam tahap ini penulis mencoba untuk mengidentifikasi permasalahan yang ada. Tahap ini menjelaskan tahap awal pada penyusunan penelitian ini. Hasil dari identifikasi inilah yang menjadi objek penelitian. Masalah yang diidentifikasi adalah bagaimana merancang suatu aplikasi pengenalan wajah (face recognition) dengan menggunakan metode Principal Componen Analysis.

\section{Pengumpulan Data Penelitian}

Untuk mendapatkan data yang mendukung penelitian ini, penulis menggunakan metode yaitu:

a. Studi Pustaka

Metode pengumpulan data dalam penulisan ini menggunakan studi kepustakaan guna menunjang pembuatan tugas akhir dengan membaca dan mempelajari buku-buku literatur, jurnal, artikel yang berhubungan dengan pengenalan citra berbasis komputer khususnya pengenalan wajah manusia.

b. Survei

Survei yang dilakukan dalam penelitian ini adalah melakukan pengumpulkan citra wajah yang digunakan sebagai sampel untuk database dan uji coba dalam aplikasi ini. Adapun sampel sebanyak 10 orang dengan kriteria sebagai berikut :

Tabel 3.1 Kriteria Sampel

\begin{tabular}{lll}
\hline Pria & Wanita & Ekspresi \\
\hline $\begin{array}{l}\text { Pakai } \\
\text { Kacamata }\end{array}$ & Berjilbab & Senyum \\
\hline $\begin{array}{l}\text { Tidak Pakai } \\
\text { Kacamata }\end{array}$ & $\begin{array}{l}\text { Berjilbab } \\
\text { pakai } \\
\text { Kacamata }\end{array}$ & Normal \\
\hline Berkumis & & Ketawa \\
\hline
\end{tabular}

\section{Kerangka Pengembangan Aplikasi}

Kerangka pengembangan aplikasi yang digunakan adalah sequential linier (waterfall). Penjelasan tahapan yang dilakukan dalam penelitian ini adalah sebagai berikut :

1. Analysis. Merupakan tahap menganalisis hal-hal yang diperlukan dalam pelaksanaan proyek pembuatan perangkat lunak.

2. Design. Tahap penerjemahan dari data yang dianalisis kedalam bentuk yang mudah dimengerti. 
3. Coding. Tahap penerjemahan data atau pemecahan masalah yang telah dirancang kedalam bahasa pemrograman $\mathrm{CH}$.

4. Testing. Merupakan tahap pengujian terhadap perangkat lunak yang dibangun.

5. Maintenance. Tahap akhir dimana suatu perangkat lunak yang sudah selesai dapat mengalami perubahan-perubahan atau penambahan sesuai dengan kebutuhan.

\section{HASIL}

pengenalan wajah dalam keadaan yang telah dikondisikan sebelumnya.

Berdasarkan kebutuhan sistem dan hasil analisis, maka sistem yang akan dibuat harus dapat memenuhi fungsi-fungsi sebagai berikut:

1. Mengimplementasikan metode Principal Componen Analysis pada sistem pengenalan wajah.

2. Menguji performa dan kemampuan metode Principal Componen Analysis pada sistem pengenalan wajah dalam keadaan yang telah dikondisikan sebelumnya.

3. Menghasilkan sebuah kesimpulan berapa tingkat akurasi metode Principal Componen Analysis dalam sistem pengenalan wajah.

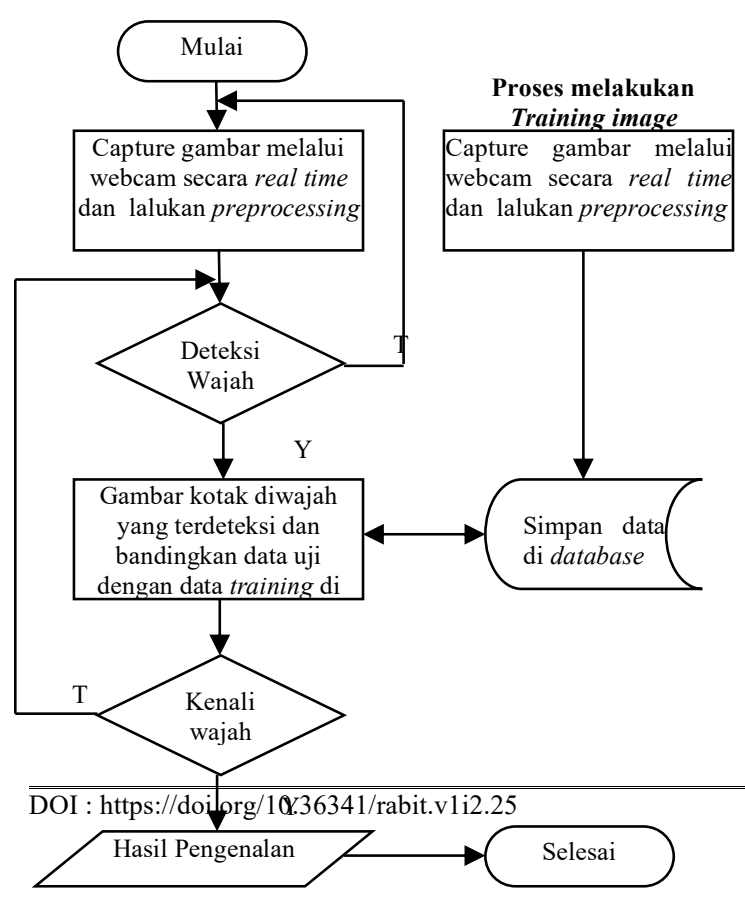

\section{Gambar 4. Flowchart Sistem}

\section{Perancangan Sistem}

Proses dari sistem pengenalan wajah menggunakan metode Principal Componen Analysis ini terdapat beberapa komponen yang dapat digambarkan dalam blok diagram. Setelah itu akan dilakukan proses perancangan aplikasi.

Diagram Blok Pengenalan Wajah

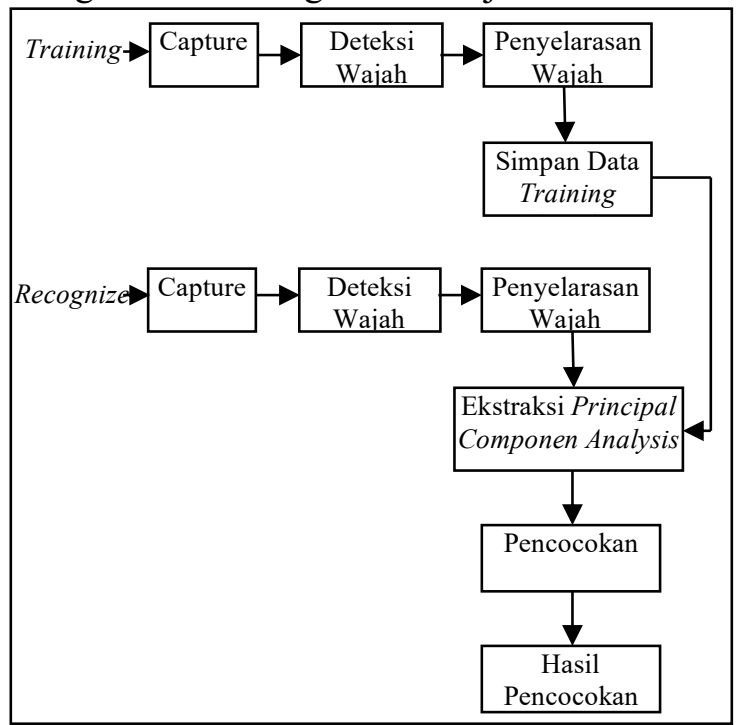

Gambar 3. Diagram Blok Pengenalan Wajah

Berdasarkan pada gambar 4.1 diatas dapat dijelaskan bahwa komponen training merupakan data wajah yang akan dilatih dan disimpan dalam database yang nantinya akan digunakan untuk proses pencocokan wajah dengan data wajah yang diuji, sedangkan komponen recognizer merupakan data wajah yang akan diuji dan dicocokan dengan data wajah yang ada di dalam database, yang mana jika ada kemiripan dengan data uji dengan data latih, maka hasil pencocokan akan ditampilkan.

Berikut contoh sampel data training dari sistem pengenalan wajah menggunakan metode PCA : 


\section{RABIT : Jurnal Teknologi dan Sistem Informasi Univrab}

Volume 1 No. 2 | Juli 2016 : 61-77

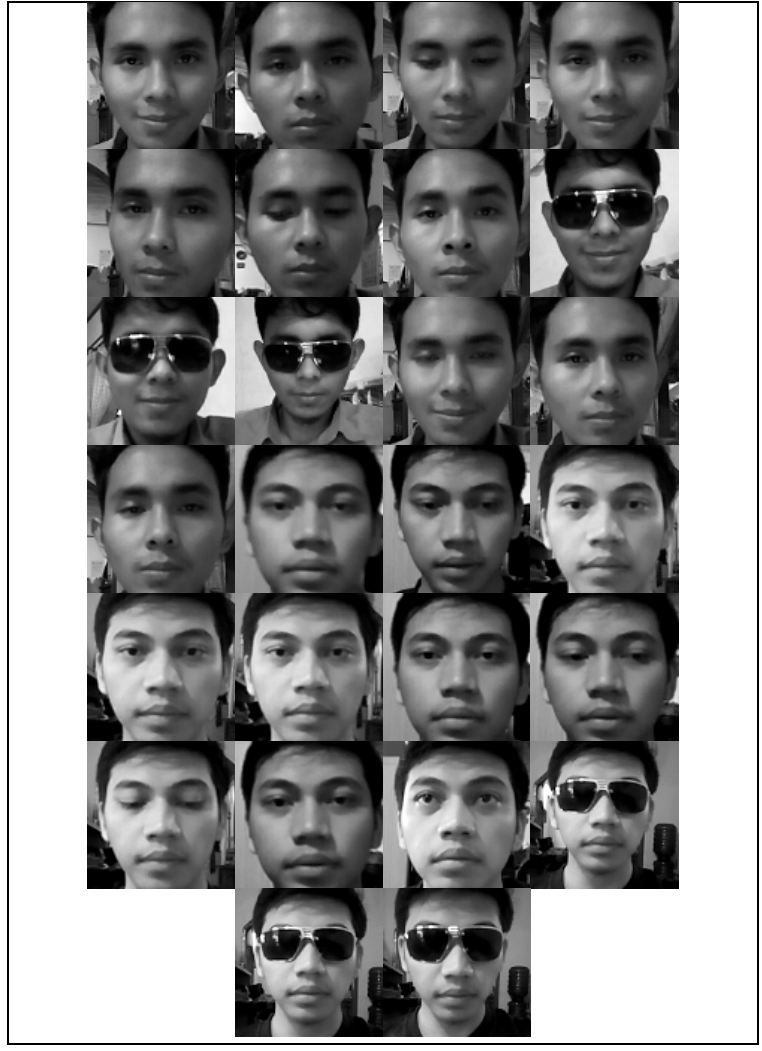

Gambar 5. Contoh Data Sampel

Penjelasan mengenai proses pengenalan wajah menggunakan PCA, Untuk lebih jelasnya algoritma PCA dapat diuraikan dalam ilustrasi sebagai berikut :

\section{Penyusunan Flatvector matriks citra}

Langkah pertama adalah menyusun seluruh training image menjadi 1 matriks tunggal. Misalnya image yang kita simpan berukuran $\mathrm{H} \times \mathrm{W}$ piksel dan jumlahnya $\mathrm{N}$ buah, maka memiliki flatvector dengan dimensi $\mathrm{N} \times(\mathrm{H} \times \mathrm{W})$. representasikan semua matriks training menjadi matriks dengan bentuk $\mathrm{N} \times 1$ atau matriks linier seperti yang ditunjukkan berikut ini:

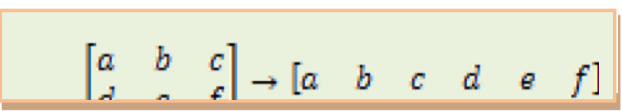

Gambar 6. Skema Matriks Wajah

Misalnya didalam training image terdapat tiga image ukuran $3 \times 3$ piksel maka kita akan mempunyai eigenvector ukuran $2 \times 9$.
Contoh dibawah ini mengunakan empat wajah citra yang telah diubah menjadi matriks, lalu matriks tersebut diubah kedalam bentuk rataan FlatVector.

\section{Hitung Rataan FlatVector}

Dari FlatVector yang diperoleh, jumlahkan seluruh barisnya sehingga kita peroleh matriks berukuran $1 \times(\mathrm{H} \mathrm{x} \mathrm{W})$.

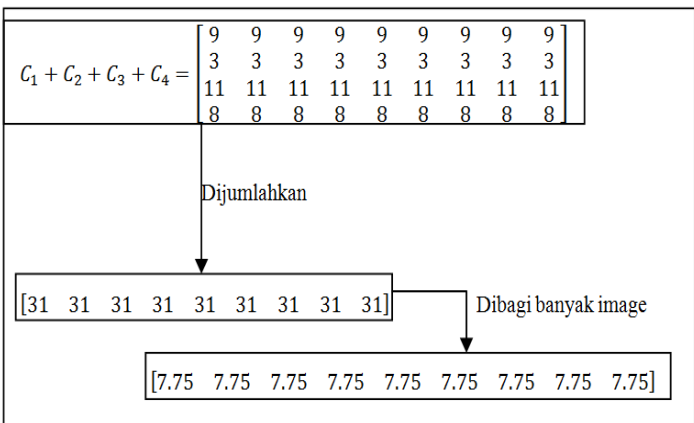

Gambar 6. Rataan FlatVector

Nilai flatvector citra akan digunakan untuk menghitung nilai eigenface citra wajah untuk training image.

2. Tentukan nilai eigenface

Dengan memakai rataan flatvector citra di atas nilai eigenface untuk matriks flatvector yang sudah disusun tersebut dapat dihitung nilai eigenfacenya. Caranya dengan mengurangi baris-baris pada matrix flatvector dengan rataan flatvector. Jika didapatkan nilai dibawah nol, maka nilainya diganti dengan nol.

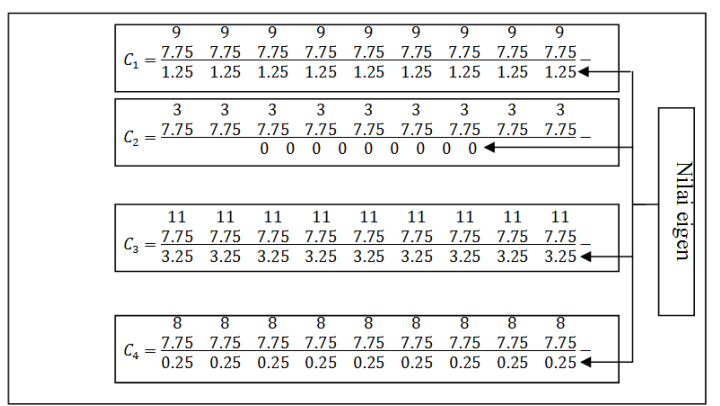


Gambar 7. Hitung Nilai Eigen Citra Training

\section{Proses Identifikasi}

Untuk mengenali citra tes (testface), langkah identifikasinya adalah hitung nilai eigenface untuk matriks testface dengan cara sebelumnya untuk penentuan nilai eigenface dan flatvector citranya.

Nilai eigen (eigenvalue) dari testface digunakan untuk identifikasi dengan menentukan jarak terpendek dengan eigenface dari eigenvector training dengan cara menentukan nilai absolut dari pengurangan baris I pada matriks eigenface training citra dengan eigenface dari testface dan jumlahkan dengan elemen penyusun vector yang dihasilkan dari pengurangan dan didapat jarak indeks I dan cari nilai yang paling kecil. Setelah nilai eigenface untuk testface diperoleh maka kita bisa melakukan identifikasi dengan menentukan jarak terpendek dengan eigenface dari eigenvector training image. Pertama tentukan nilai absolut dari pengurangan baris pada matriks eigenface training image dengan eigenface dari testface, kemudian jumlahkan elemen-elemen penyusun vector yang dihasilkan dari pengurangan tadi dan ditemukan jarak indeks. Lakukan untuk semua baris. Cari nilai yang paling kecil.

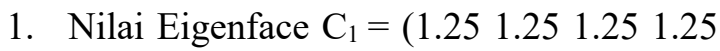

1.25 1.251 .251 .251 .25$)$

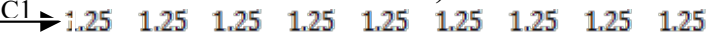

$\stackrel{\mathrm{Ct}}{\longrightarrow}$\begin{tabular}{ccccccccc}
1.25 & 1.25 & 1.25 & 1.25 & 0 & 1.25 & 1.25 & 1.25 & 0.25 \\
\hline 0 & 0 & 0 & 0 & 1.25 & 0 & 0 & 0 & 1
\end{tabular}

Nilai jarak :

$=0+0+0+0+1.25+0+0+1$

$=2.25$

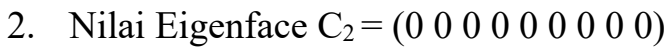

$$
\begin{aligned}
& \begin{array}{lllllllll}
0 & 0 & 0 & 0 & 0 & 0 & 0 & 0 & 0
\end{array} \\
& \stackrel{\mathrm{C} 2}{\longrightarrow} \rightarrow \begin{array}{ccccccccc}
1.25 & 1.25 & 1.25 & 1.25 & 0 & 1.25 & 1.25 & 1.25 & 0.25 \\
--1.25 & -1.25 & -1.25 & -1.25 & 0 & -1.25 & -1.25 & -1.25 & 0.25
\end{array} \\
& \text { Nilai jarak : } \\
& =1.25+1.25+1.25+1.25+1.25+1.25+1.25+1 \\
& =11
\end{aligned}
$$

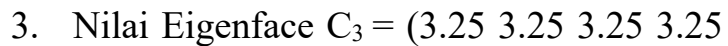

$$
3.253 .253 .253 .253 .25 \text { ) }
$$

$\begin{array}{llllllllll}\text { C3 } & 3.25 & 3.25 & 3.25 & 3.25 & 3.25 & 3.25 & 3.25 & 3.25 & 3.25\end{array}$

Ct $\quad \begin{array}{ccccccccc}1.25 & 1.25 & 1.25 & 1.25 & 0 & 1.25 & 1.25 & 1.25 & 0.25 \\ 2 & 2 & 2 & 2 & 3.25 & 2 & 2 & 2 & 3\end{array}$

Nilai jarak :

$=2+2+2+2+3.25+2+2+2+3$

$=18.25$

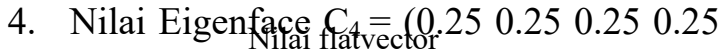
$\begin{array}{lllll}0.25 & 0.25 & 0.25 & 0.25 & 0.25)\end{array}$

$\begin{array}{llllllllll}\mathrm{C} 1 & 0.25 & 0.25 & 0.25 & 0.25 & 0.25 & 0.25 & 0.25 & 0.25 & 0.25\end{array}$ \begin{tabular}{cccccccccc}
$\mathrm{C} t$ & 1.25 & 1.25 & 1.25 & 1.25 & 0 & 1.25 & 1.25 & 1.25 & 0.25 \\
\hline-1 & -1 & -1 & -1 & 0.25 & -1 & -1 & -1 & -1
\end{tabular}

Nilai jarak :

$=1+1+1+1+0.25+1+1+1+1$

$=8.25$

Dari hasil perhitungan, diperoleh jarak citra wajah citra satu memiliki nilai yang terkecil yaitu 2.25. Karena jarak eigenface satu dengan testface yang paling kecil, maka hasil identifikasi menyimpulkan bahwa testface lebih mirip dengan face satu dari pada face dua, face tiga dan face empat.

\section{Flowchart Training Wajah}

Pada proses ini akan dilakukan pembelajaran terhadap citra yang akan disimpan ke dalam database. Hasil dari pembelajaran ini kemudian disimpan dengan format *.xml dan digunakan untuk proses pencocokan. 


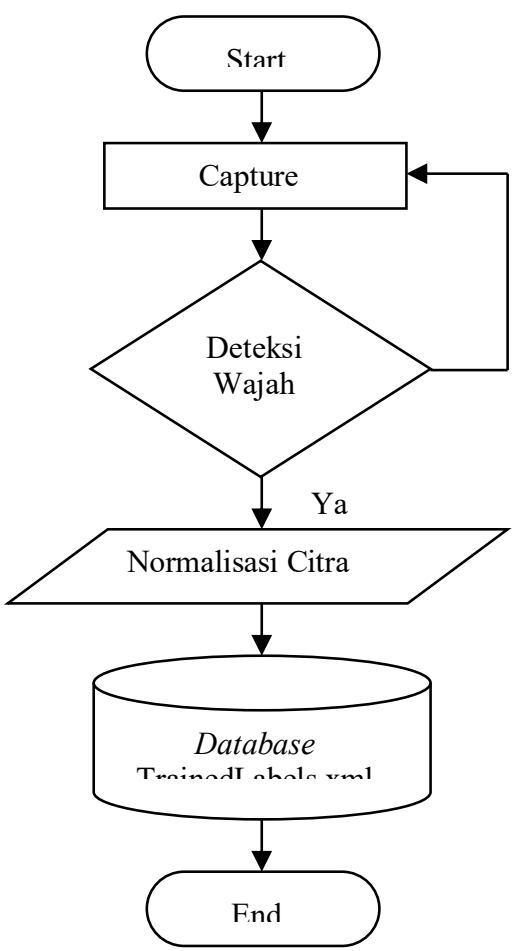

Gambar 8. Flowchart Training Wajah

Dari gambar diatas, langkah Training wajah dapat dijelaskan sebagai berikut :

1. Mulai dari start, input dimulai dengan mengambil capture dari webcam

2. Setelah melakukan capture, langkah selanjutnya mendeteksi wajah. Jika wajah tidak terdeteksi kembali ke proses capture. Sedangkan jika terdeteksi, akan berlanjut.

3. Setelah wajah terdeteksi, langkah selanjutnya adalah proses normalisasi citra. Normalisasi tersebut meliputi resizing citra $100 \times 100$ pixel dan setelahnya dilakukan perubahan format gambar dari RGB ke grayscale.

4. Setelah proses normalisasi citra, selanjutnya adalah data Training akan disimpan kedalam database yang berformat*.xml.

5. Proses selesai.

\section{Flowchart Sistem Pengenalan Wajah}

Berikut perancangan flowchart dari sistem pengenalan wajah menggunakan metode Principal Componen Analysis, dan metode euclidean distance untuk proses pencocokan wajah.

Tidak

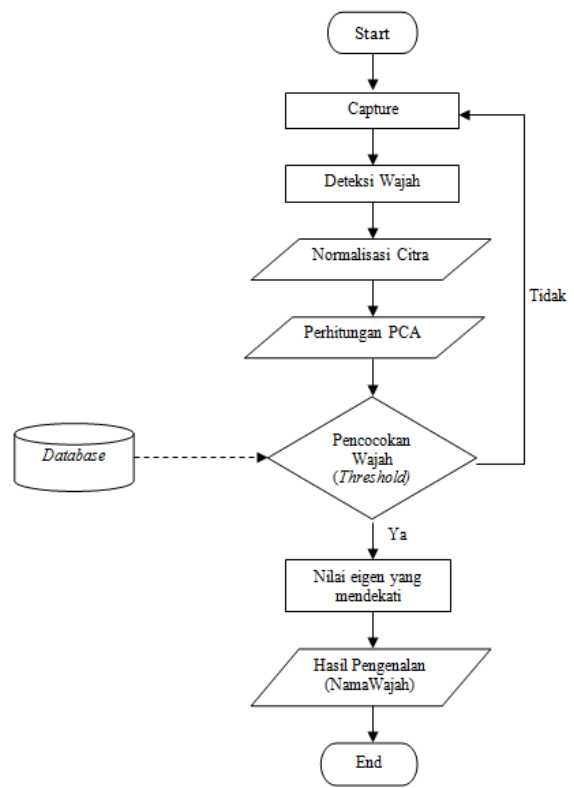

Gambar 9. Flowchart Proses Pengenalan Wajah

Dari gambar diatas, langkah pengenalan wajah dapat dijelaskan sebagai berikut :

1. Mulai dari start, input dimulai dengan mengambil capture dari webcam

2. Setelah melakukan capture, langkah selanjutnya mendeteksi wajah.

3. Setelah wajah terdeteksi, langkah selanjutnya adalah proses normalisasi citra. Normalisasi tersebut meliputi resizing citra $100 \times 100$ pixel dan setelahnya dilakukan perubahan format gambar dari RGB ke grayscale, kemudian dari grayscale tersebut diubah lagi menjadi bentuk matriks.

4. Setelah proses normalisasi citra, selanjutnya adalah proses perhitungan Principal Componen Analysis data citra uji dengan data citra yang ada di 
database dengan ketentuan data wajah yang akan dikenali diatas nilai Threshold.

5. Tahap selanjutnya adalah pencocokan nilai PCA input dengan PCA data training (database) menggunakan metode euclidean distance, jika tidak cocok kembali ke proses capture. Sedangkan jika cocok, akan berlanjut.

6. Selanjutnya jika cocok, akan dicari nilai eigen yang mendekati.

7. Setelah ditemukan kemiripan (nilai eigen yang mendekati) dengan citra wajah, hasil nama pengenalan wajah akan ditampilkan.

8. Proses selesai.

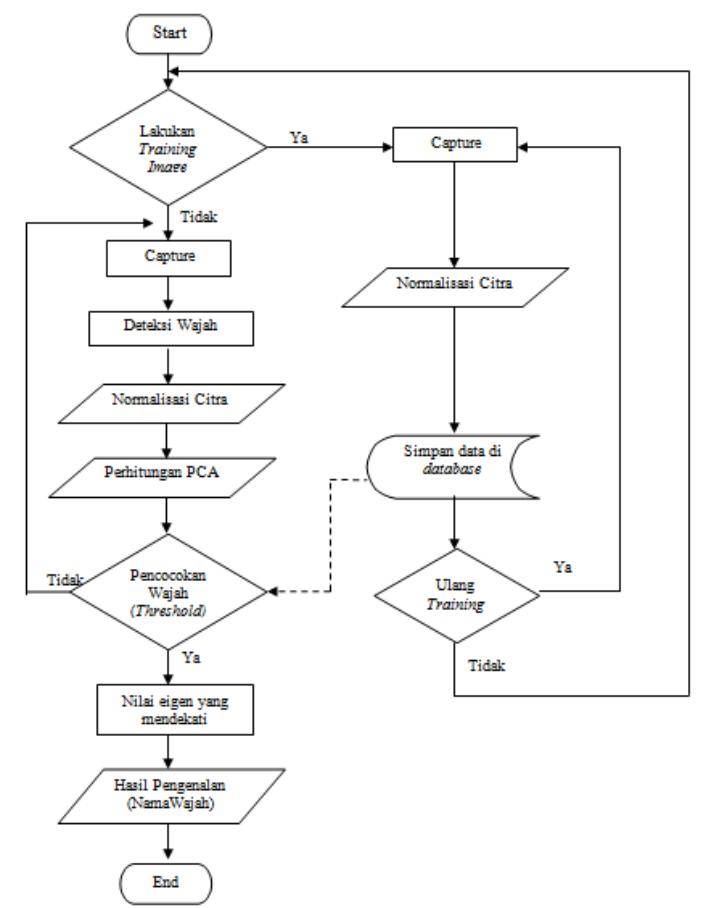

Gambar 11. Flowchart Aplikasi

\section{Implementasi}

Implementasi merupakan tahapan setelah melakukan analisis dan perancangan sistem pada siklus rekayasa perangkat lunak, dimana aplikasi siap untuk dioperasikan pada keadaan yang sebenarnya sehingga akan diketahui apakah program yang telah dibuat benar-benar dapat menghasilkan sebuah keluaran yang sesuai dengan tujuan yang diinginkan.

\section{Desain User Interface}

Pembuatan User Interface pengenalan wajah menggunakan sarana yang diberikan oleh Visual Studio 2010, User Interface berguna untuk mempermudahkan pengguna didalam penginputan data yang dibutuhkan untuk sistem.

\section{Tampilan Form Utama}

Form utama merupakan tampilan awal dari aplikasi pengenalan wajah, yang mana dalam form utama ini terdapat 3 menustrip, 1 picturebox, dan beberapa komponen lainnya. Gambar 4.6 dibawah ini merupakan tampilandari form utama.

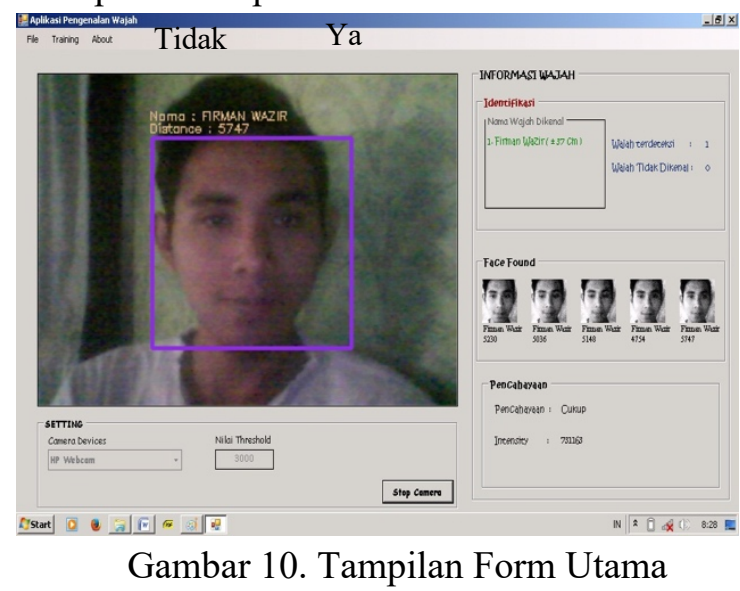

Form utama ini guna untuk proses pengenalan wajah, yang mana komponen picturebox merupakan sebagai webcam. Pada komponen groupbox setting terdapat 1 combobox, 1 Textbox dan 1 button, komponen combobox digunaka untuk memilih devices camera yang akan digunakan, sedangkan komponen Textbox digunakan untuk mengatur nilai threshold (nilai ambang batas), nilai threshold ini untuk menentukan batas nilai pencocokan wajah yang jika nilai jarak kemiripan berada diatas threshold, maka wajah dikenali dan jika dibawah threshold 
wajah tidak dikenali. Sedangkan Tombol button pada komponen groupbox setting digunakan untuk yang jika di-klik maka capture dari webcam akan ditampilkan sesuai devices camera yang telah dipilih. Komponen groupbox informasi wajah guna sebagai informasi dari wajah yang dideteksi, baik wajah yang dikenali atau yang tidak dikenali, komponen ini akan menampilkan informasi sesuai hasil dari proses pengenala wajah.

Dalam form utama juga terdapat beberapa komponen menustrip, diantaranya menustrip training, menu ini digunakan untuk masuk ke form proses training image (proses pelatihan wajah), yang mana proses training untuk pembelajaran citra wajah yang nantinya digunakan untuk proses pencocokan wajah pada form utama proses pengenalan wajah.

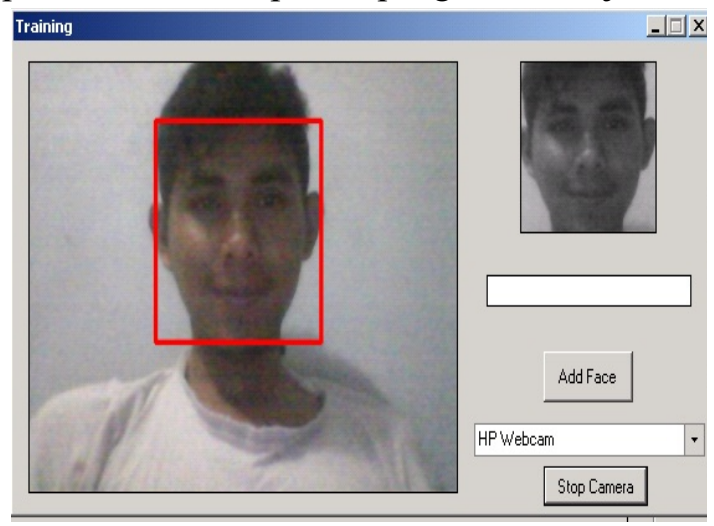

Gambar 11. Tampilan Form Training
Gambar 4.7 merupakan form untuk melakukan training citra wajah, form training ini guna untuk melakukan pembelajaran pada citra wajah dan hasil pembelajaran itu akan disimpan kedalam database yang berformat *.xml untuk dijadikan sampel. Data sampel ini yang akan digunakan untuk proses pencocokan wajah dengan data wajah uji.

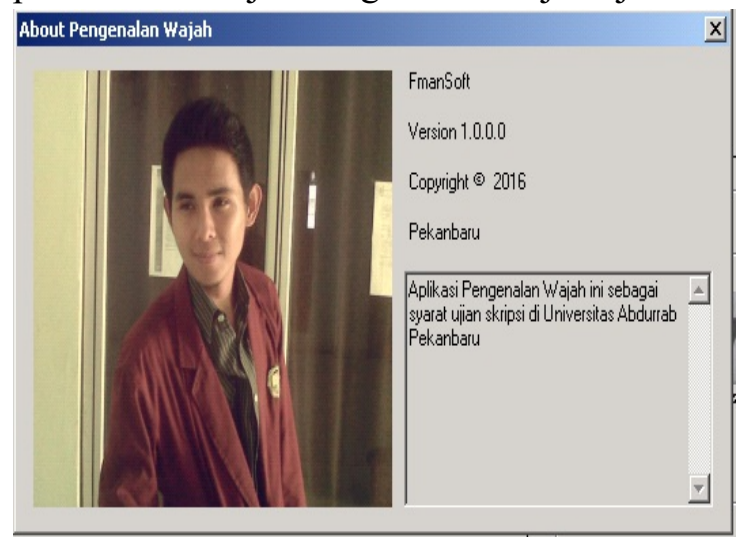

Gambar 12. Tampilan Form Profile

\section{Pengujian Sistem Pengenalan Wajah}

Pengujian ini dimaksudkan untuk mengetahui akurasi sistem pengenalan wajah dengan menggunakan jumlah data training dan data yang diuji yang berbeda. Berikut hasil untuk pengujian pengenalan wajah :

Tabel 1. Hasil Pengujian Pertama

\begin{tabular}{|c|c|c|c|c|c|}
\hline $\begin{array}{l}\text { Data Wajah } \\
\text { Yang Diuji }\end{array}$ & $\begin{array}{r}\text { Jenis } \\
\text { Kelamin }\end{array}$ & Atribut & $\begin{array}{l}\text { Ekspr } \\
\text { esi }\end{array}$ & Hasil & $\begin{array}{r}\text { Presentase } \\
\text { Keberhasilan }\end{array}$ \\
\hline & \multirow{6}{*}{$\begin{array}{l}\text { Laki- } \\
\text { Laki }\end{array}$} & Kacamata & $\begin{array}{l}\text { Seny } \\
\text { um }\end{array}$ & $\begin{array}{l}\text { Diken } \\
\text { ali }\end{array}$ & \multirow{6}{*}{$\begin{array}{c}6 / 6 * \\
100 \% \\
=100 \%\end{array}$} \\
\hline & & Kacamata & $\begin{array}{l}\text { Norm } \\
\text { al }\end{array}$ & $\begin{array}{l}\text { Diken } \\
\text { ali }\end{array}$ & \\
\hline & & Kacamata & Sedih & $\begin{array}{l}\text { Diken } \\
\text { ali }\end{array}$ & \\
\hline Firman & & Tanpa & Seny & Diken & \\
\hline \multirow[t]{2}{*}{ Wazir } & & Kacamata & um & ali & \\
\hline & & $\begin{array}{r}\text { Tanpa } \\
\text { Kacamata }\end{array}$ & $\begin{array}{l}\text { Norm } \\
\text { al }\end{array}$ & $\begin{array}{l}\text { Diken } \\
\text { ali }\end{array}$ & \\
\hline
\end{tabular}




\begin{tabular}{lll}
\hline $\begin{array}{r}\text { Tanpa } \\
\text { Kacamata }\end{array}$ & Sedih & $\begin{array}{l}\text { Diken } \\
\text { ali }\end{array}$ \\
\hline
\end{tabular}

Berdasarkan hasil pengujian terhadap sampel data wajah pertama yang ditunjukan pada tabel 4.1, dilakukan pengujian sebanyak
6 kali. Hasil pengujian menunjukkan presentase tingkat keberhasilan (akurasi) yaitu $100 \%$.

Tabel 2 Hasil Pengujian Kedua

\begin{tabular}{|c|c|c|c|c|c|}
\hline $\begin{array}{l}\text { Data Wajah } \\
\text { Yang Diuji }\end{array}$ & $\begin{array}{c}\text { Jenis } \\
\text { Kelamin }\end{array}$ & Atribut & Ekspresi & Hasil & $\begin{array}{c}\text { Presentase } \\
\text { Keberhasilan }\end{array}$ \\
\hline & \multirow{6}{*}{ Laki-Laki } & Kacamata & Senyum & Dikenali & \multirow{6}{*}{$\begin{array}{l}6 / 6 * 100 \% \\
\quad=100 \%\end{array}$} \\
\hline & & Kacamata & Normal & Dikenali & \\
\hline & & Kacamata & Sedih & Dikenali & \\
\hline & & $\begin{array}{c}\text { Tanpa } \\
\text { Kacamata }\end{array}$ & Senyum & Dikenali & \\
\hline \multirow[t]{2}{*}{ Tony } & & $\begin{array}{c}\text { Tanpa } \\
\text { Kacamata }\end{array}$ & Normal & Dikenali & \\
\hline & & $\begin{array}{c}\text { Tanpa } \\
\text { Kacamata }\end{array}$ & Sedih & Dikenali & \\
\hline
\end{tabular}

Hasil pengujian terhadap sampel data wajah kedua yang ditunjukan pada tabel 4.2, dilakukan pengujian sebanyak 6 kali. Hasil pengujian menunjukkan presentase tingkat keberhasilan (akurasi) sama dengan hasil pengujian sampel yang pertama yaitu $100 \%$.

Tabel 3 Hasil Pengujian Ke Tiga

\begin{tabular}{|c|c|c|c|c|}
\hline $\begin{array}{l}\text { Data Wajah } \\
\text { Yang Diuji }\end{array}$ & $\begin{array}{c}\text { Jenis } \\
\text { Kelamin }\end{array}$ & Ekspresi & Hasil & $\begin{array}{c}\text { Presentase } \\
\text { Keberhasilan }\end{array}$ \\
\hline & \multirow{6}{*}{ Laki-Laki } & Senyum & Dikenali & \multirow{6}{*}{$\begin{array}{c}5 / 6 * 100 \% \\
=83 \%\end{array}$} \\
\hline & & Sedih & Dikenali & \\
\hline & & Normal & Dikenali & \\
\hline & & Normal & Dikenali & \\
\hline \multirow[t]{2}{*}{ Rizki } & & Sedih & Tidak & \\
\hline & & Senyum & Dikenali & \\
\hline
\end{tabular}

Hasil pengujian terhadap sampel wajah ketiga pada tabel 4.3, dilakukan pengujian sebanyak 6 kali, Hasil pengujian menunjukkan presentase tingkat keberhasilan (akurasi) yaitu $83 \%$. 
RABIT : Jurnal Teknologi dan Sistem Informasi Univrab

Volume 1 No. 2 | Juli 2016 : 61-77

Tabel 4 Hasil Pengujian Ke Empat

\begin{tabular}{|c|c|c|c|c|c|}
\hline $\begin{array}{l}\text { Data Wajah } \\
\text { Yang Diuji }\end{array}$ & $\begin{array}{c}\text { Jenis } \\
\text { Kelamin }\end{array}$ & Atribut & Ekspresi & Hasil & $\begin{array}{r}\text { Presentase } \\
\text { Keberhasilan }\end{array}$ \\
\hline & & $\begin{array}{c}\text { Kacamata, } \\
\text { Jilbab }\end{array}$ & Senyum & Tidak & \\
\hline & & $\begin{array}{c}\text { Kacamata, } \\
\text { Jilbab }\end{array}$ & Sedih & Tidak & \\
\hline & & $\begin{array}{c}\text { Kacamata, } \\
\text { Jilbab }\end{array}$ & Senyum & Dikenali & \\
\hline & \multirow{7}{*}{ Perempuan } & $\begin{array}{c}\text { Kacamata, } \\
\text { Jilbab }\end{array}$ & Normal & Dikenali & \multirow{7}{*}{$\begin{array}{c}6 / 10 * \\
100 \% \\
=60 \%\end{array}$} \\
\hline & & $\begin{array}{c}\text { Kacamata, } \\
\text { Jilbab }\end{array}$ & Sedih & Dikenali & \\
\hline \multirow{5}{*}{ Ibu Tony } & & Jilbab & Senyum & Tidak & \\
\hline & & Jilbab & Senyum & Dikenali & \\
\hline & & Jilbab & Normal & Dikenali & \\
\hline & & Jilbab & Sedih & Tidak & \\
\hline & & Jilbab & Sedih & Dikenali & \\
\hline
\end{tabular}

Hasil pengujian terhadap sampel data wajah keempat pada tabel 4.4, dilakukan pengujian sebanyak 10 kali, karena pengaruh pencahayaan yang membuat wajah kadang dikenali dan tidak dikenali. Hasil pengujian menunjukkan presentase tingkat keberhasilan (akurasi) yaitu 60\%.

Tabel 5 Hasil Pengujian Ke Lima

\begin{tabular}{|c|c|c|c|c|c|}
\hline $\begin{array}{c}\text { Data Wajah } \\
\text { Yang Diuji }\end{array}$ & $\begin{array}{c}\text { Jenis } \\
\text { Kelamin }\end{array}$ & Cahaya & Ekspresi & Hasil & $\begin{array}{c}\text { Presentase } \\
\text { Keberhasilan }\end{array}$ \\
\hline \multirow{9}{*}{ Irham } & \multirow{9}{*}{ Laki-Laki } & Terang & Senyum & Dikenali & \multirow{9}{*}{$\begin{array}{c}8 / 10 * 100 \% \\
=80 \%\end{array}$} \\
\hline & & Terang & Sedih & Dikenali & \\
\hline & & Terang & Normal & Dikenali & \\
\hline & & Cukup & Normal & Dikenali & \\
\hline & & Cukup & Sedih & Dikenali & \\
\hline & & Cukup & Senyum & Dikenali & \\
\hline & & Kurang & Senyum & Tidak & \\
\hline & & Kurang & Normal & Dikenali & \\
\hline & & Kurang & Sedih & Tidak & \\
\hline
\end{tabular}




\begin{tabular}{lll}
\hline Kurang & Sedih & Dikenali \\
\hline
\end{tabular}

Hasil pengujian terhadap sampel wajah kelima pada tabel 4.5, dilakukan pengujian sebanyak 10 kali, Hasil pengujian menunjukkan presentase tingkat keberhasilan (akurasi) yaitu $80 \%$. Pengujian ini menunjukkan bahwa pencahayaan untuk akurasi pengenalan wajah sangat mempengaruhi. Walau pada tabel diatas akurasi pengenalan wajah menunjukkan lumayan bagus, tapi sewaktu-sewaktu jika diuji kembali hasilnya bisa berbeda, itu karena pencahayaan dan juga kualitas citra sampel yang diambil tidak sama rata dengan citra sampel yang lainnya.

Berdasarkan pengujian yang dilakukan, tingkat keberhasilan pengenalan wajah menggunakan metode principal component analysis dengan 38 kali pengujian adalah $81 \%$ sukses dikenali dan $29 \%$ gagal dikenali. Penyebab kurangnya keakuratan dalam pengenalan wajah menggunakan metode principal component analysis ini adalah :

1. Sensitif terhadap cahaya

2. Jarak wajah dari kamera terlalu jauh

3. Perubahan wajah yang terlalu ekstrim Ekspresi wajah

\section{KESIMPULAN}

Pada bab ini dijelaskan kesimpulan yang diambil berdasarkan analisa dan saran yang diambil berdasarkan hasil pengujian yang telah dilakukan.

Kesimpulan dari Tugas Akhir ini berdasarkan pengujina, hasil dan analisa adalah :

1. Pengenalan pola wajah dapat dikenali menggunakan nilai pixel dari data wajah.

2. Proses pengenalan wajah menggunakan pendekatan metode Principal Componen Analysis sensitif terhadap perubahan cahaya, jarak, ekspresi wajah, sudut pandang wajah dan perubahan wajah yang terlalu ekstrim. Jika citra yang digunakan sebagai training set maupun sebagai citra input memiliki intensitas cahaya yang berbeda dan tidak berada pada posisi yang sama dengan citra training set maka proses tersebut tidak dapat memberikan hasil yang akurat

3. metode Principal Componen Analysis dapat diimplementasikan untuk pengenalan wajah dengan tingkat akurasi $81 \%$.

4. Wajah dapat dikenali apabila nilai jarak antara image training dengan image test diatas nilai threshold.

\section{DAFTAR PUSTAKA}

[1]. Damayanti, Fitri, Agus Zainal Abidin dan Rully Soelaiman. 2010. Pengenalan Citra Wajah Menggunakan Metode Two-Dimensional Linear Discriminant Analysis dan Support Vector Machine. Jurnal Ilmiah Kursor, Vol.5, No.3

[2]. Fatta, Hanif Al. 2009. Rekayasa Sistem Pengenalan Wajah. Andi: Yogyakarta.

[3]. Ismawan, Fiqih. 2015. Hasil Ekstraksi Algoritma Principal Component Analysis (PCA) Untuk Pengenalan Wajah Dengan Bahasa Pemrograman Java Eclipse IDE. Sisfotek Global, Vol.5, No.1

[4]. Lestari, Sri Puji. 2014. Implementasi Pengenalan Wajah Manusia Menggunakan Principal Component Analysis (PCA). Pelita Informatika Budi Darma, Vol.6, No. 2.

[5]. Marti, Ni Wayan. 2010. Pemanfaatan gui dalam pengembangan perangkat lunak Pengenalan citra wajah manusia menggunakan metode Eigenfaces. Seminar Nasional Aplikasi Teknologi Informasi 2010: Yogyakarta 
[6]. Pratiwi, Dian Esti dan Agus Harjoko. 2013. Implementasi Pengenalan Wajah menggunakan PCA (Principal Component Analysis). Ijeis, Vol.3, No.2

[7]. Rejeki, Muslim Setyo dan Ali Tarmuji. 2013. Membangun aplikasi autogenerate script ke Flowchart untuk mendukung business process Reengineering. Jurnal Sarjana Teknik Informatika, Vol.1, No.2

[8]. Sembiring, Maha Kinnoy. 2015. Perancangan Aplikasi Pengenalan Wajah Menggunakan Metode Fisher Linear Discriminant (FLD). Pelita Informatika Budi Darma, Vol.9, No.1

[9]. Suryanto, Agus dan Samiyono. 2011. Implementasi Model Analisis Perbaikan Faktor Daya Listrik Rumah Tangga dengan Simulasi Perangkat Lunak. Jurnal Kompetensi Teknik, Vol.3, No.1

[10].Indra. 2012. Sistem Pengenalan Wajah Dengan Metode Eigenface Untuk Absensi Pada PT. Florindo Lestari. Seminar Nasional Teknologi Informasi \& Komunikasi Terapan 2012. ISBN 979-26-0255-0

[11].Muliawan, Muhammad Rizki, Beni Irawan dan Yulrio Brianorman. Implementasi Pengenalan Wajah Dengan Metode Eigenface Pada Sistem Absensi. Jurnal Coding. Vol. 3, No. 1 